\title{
Kualitas Pengasuhan Anak dan Celah Kekerasan di Panti Sosial Asuhan Anak: Studi Kasus di PSAA Darul Aitam Nahdlatul Wathan, Kabupaten Lombok Timur Provinsi Nusa Tenggara Barat ${ }^{1}$
}

\author{
Lisma Dyawati Fuaida
}

\begin{abstract}
Abstrak
This paper presents a research findings about the picture of children in the "panti" (childcare institutions). The phenomenon of many children who live in the "panti" are still have complete parents who still live at home. This is a picture of the large number of childcare institutions in Indonesia, both organized by community and by religious organizations. This research aimed to explain the detail assessment of the quality of child care in the Darul Aitam Nahdlatul Wathan, Lombok, in September 2006. The research method is qualitative by using 5 (five) aspects of quality of service as a conceptual framework: 1) professional practice, 2) personal care, 3) staffing, 4) sources; 5) administration. The results showed that there are so many things should be addressed based on those aspects in childcare institution.
\end{abstract}

Key words: kekerasan anak, pengasuhan, panti sosial asuhan anak, hak anak.

\section{Pendahuluan}

Panti Sosial Asuhan Anak (PSAA) biasa dikenal dengan sebutan Panti Asuhan di mana anak-anak yatim piatu tinggal, diasuh, dan dipenuhi kebutuhannya sehari-hari. Seiring dengan berjalannya waktu, tidak hanya anak-anak yatim piatu yang "dititipkan" di panti asuhan, tetapi anak-anak yang masih punya salah satu atau kedua orang tua lengkap dari keluarga miskin - yang dalam kategori anak asuh di panti disebut "anak terlantar"juga menjadi penghuni sebagian besar panti. Fenomena ini sesuai dengan data BPS yang mengatakan bahwa dari 60 juta anak Indonesia dengan usia kurang dari lima tahun, 2,15 juta di antaranya tidak hidup dengan orang tua. Padahal 72,5 persen dari 2,15 juta anak itu masih memiliki orang tua hidup dan 15,5 persen masih memiliki satu orang tua, dan hanya 10 persen yang yatim piatu (Martin, dkk, 2007: 26).

Masyarakat Indonesia menganggap panti asuhan merupakan tempat alternatif pengasuhan anak ketika keluarga tidak lagi dianggap atau menganggap dirinya mampu menyelenggarakan pengasuhan yang baik. Ada banyak sekali anak-anak yang masih memiliki orang tua lengkap tinggal di panti. Jumlah panti pun di seluruh Indonesia sangat banyak, kurang lebih 5.250 hingga 8. 610 panti asuhan (Martin, dkk. 2007, hal. 23). Angka ini merupakan angka yang sangat besar dan memungkinkan Indonesia menjadi negara dengan jumlah panti asuhan terbanyak di dunia.

Tetapi dari jumlah tersebut, hanya sedikit saja panti milik pemerintah. Sebagian besar panti asuhan adalah milik dan dikelola oleh masyarakat, terutama organisasi keagamaan. Dari

${ }^{1}$ Tulisan ini merupakan bagian dari hasil penelitian Kualitas Pengasuhan di Panti Sosial Asuhan Anak (PSAA) di Indonesia yang dilakukan di 6 provinsi (Nanggroe Aceh Darussalam, Jawa Tengah, Nusa Tenggara Barat, Kalimantan Barat, Sulawesi Utara, dan Maluku) tahun 2006. Penelitian itu menghasilkan suatu asesmen mendalam mengenai kualitas pengasuhan di 37 panti (36 panti asuhan dan di 1 [satu] panti asuhan model nasional yang diselenggarakan oleh Depsos RI). 
fakta ini dapat dikatakan bahwa kepedulian masyarakat dalam hal penyediaan lembaga yang menampung dan melayani anak-anak kurang beruntung dalam bentuk panti asuhan dan sejenisnya cukup tinggi. Namun demikian, apakah kepedulian itu seiring dengan kepedulian dalam upaya peningkatan kualitas pengasuhan anak asuh? Bagaimana pelayanan di panti sosial asuhan anak sesuai dengan standar pengasuhan yang baik dan sejalan dengan Undang-Undang RI No. 23 tahun 2002 tentang perlindungan anak? Pertanyaan itulah yang hendak dijawab dalam penelitian ini.

Hanya sedikit penelitian yang dilakukan secara mendalam mengenai asesmen kualitas pengasuhan yang berbasis hak-hak anak. Inilah yang menjadikan penelitian ini penting paling tidak untuk tiga hal. Pertama, hasil penelitian ini dapat memperkaya literatur dalam bidang kesejahteraan anak dan praktik-praktik perlindungan anak. Kedua, hasil penelitian ini penting dibaca oleh para praktisi pengasuhan anak, terutama penyelenggara atau pengurus dan pengasuh anak di panti-panti sosial asuhan anak. Ketiga, hasil penelitian ini dapat menjadi dasar untuk mendorong pemerintah dalam membuat standar pengasuhan anak di lembaga-lembaga yang menyelenggarakan pelayanan untuk kesejahteraan anak.

\section{Metode Penelitian}

Pendekatan penelitian ini bersifat kualitatif. Penelitian dilakukan tidak untuk mencari generalisasi statistik mengenai keadaan anak-anak di panti tersebut, tetapi menyediakan studi kasus mendalam dari panti yang diteliti. PSAA Darul Aitam sendiri dipilih berdasarkan 7 (tujuh) variabel dasar yang perlu dipenuhi dalam pemilihan panti (Martin dkk., 2007, hal. 24), yaitu: 1) kepemilikan, dari segi ini PSAA Darul Aitam ini mewakili panti non-pemerintah; 2) kelompok target sasaran, dari segi ini PSAA Darul Aitam mewakili panti asuhan campuran yang mengasuh anak laki-laki dan perempuan; 3) kapasitas anak asuh, dari segi ini PSAA Darul Aitam mewakili panti yang berkapasitas lebih dari seratus orang; 4) jenis panti, dari segi ini PSAA Darul Aitam adalah panti sosial asuhan anak; 5) sistem pengasuhan yang digunakan, dari segi ini PSAA Darul Aitam menggunakan sistem panti; 6) latar sosiografis, dari segi ini PSAA Darul Aitam merupakan panti yang terletak di/dalam konteks pedesaan; 7) karakteristik lembaga pendiri/induk, dari segi ini PSAA Darul Aitam mengembangkan panti asuhan di mana panti tersebut termasuk panti yang berada dalam naungan ormas Islam Nahdlatul Wathan.

Metode penelitian yang digunakan adalah standar kualitas pengasuhan anak yang untuk pertama kali dikembangkan oleh Save the Children UK di Afrika Timur dan Afrika Tengah dan diujicoba di beberapa negara. Standar tersebut terdiri dari 5 (lima) aspek kualitas pelayanan yaitu: 1) praktik profesional; 2) personal care; 3) pengaturan staf; 4) sumber-sumber; 5) administrasi (Swales, 2006, hal.6). Standar tersebut memberikan dasar yang berguna untuk mendiskusikan kerangka kerja penelitian yang sesuai untuk Indonesia sebagai standar praktis berdasarkan pada standar internasional. Selain itu, sebagai penelitian berbasis hak-hak anak, penelitian ini mengacu pada Undang-Undang RI No. 23 tahun 2002.

Sedangkan pengumpulan data dilakukan dengan menggunakan: 1) kuesioner untuk menggambarkan profil panti dan anak-anak asuh; 2) wawancara mendalam dengan pengurus panti asuhan dan organisasi induk panti, termasuk kepala panti, para pengasuh, dan staf pendukung lainnya, para guru sekolah, anak-anak asuh, dan beberapa orang tua; 3) diskusi 
kelompok terfokus dengan staf, guru, dan anak-anak; 4) pengamatan langsung selama 2 sampai 4 hari di panti asuhan. Data yang terkumpul diperiksa silang dengan menggunakan trianggulasi antar responden/informan untuk memastikan keakuratan informasi yang terkumpul.

Penelitian ini melakukan pengumpulan dan analisis data sebagai sebuah model yang saling terjalin di antara keduanya sejak awal. Metode yang digunakan memfokuskan pada kata-kata sebagai medium dasarnya, yang diperhalus dari bentuknya pada waktu kegiatan pengumpulan data (catatan-catatan kasar, rekaman-rekaman), sehingga menjadi jelas bagi pembaca dan penganalisis manapun (Miles, 1992, 73-76).

\section{Pembahasan}

Dari sisi sasaran pelayanan atau penerima pelayanan, Panti Asuhan Darul Aitam saat ini menampung 150 anak terdiri dari anak laki-laki 85 orang dan perempuan 65 orang. Jumlah tersebut merupakan jumlah maksimum dari daya tampung yang mereka miliki. Dengan kondisi itu maka PA ini tidak memiliki ruang kosong apalagi daftar tunggu bagi anak-anak yang membutuhkan pelayanan mereka. Berikut ini adalah profil anak di panti.

\section{Status Orang Tua Anak}

Profil anak asuh di PA ini juga dapat dilihat dari status orang tua mereka seperti terlihat pada tabel di halaman berikut:

Tabel 1. Status Orang Tua Anak

\begin{tabular}{|c|l|c|c|c|}
\hline No & Status Kedua Orang Tua & Laki-laki & Perempuan & Total \\
\hline 1 & Orangtuanya masih hidup & 45 & 27 & 72 \\
\hline 2 & Yatim piatu & 3 & 6 & 9 \\
\hline 3 & Yatim & 36 & 32 & 68 \\
\hline 4 & Piatu Total & 1 & - & 1 \\
\hline \multicolumn{2}{|c|}{} & $\mathbf{8 5}$ & $\mathbf{6 5}$ & $\mathbf{1 5 0}$ \\
\hline
\end{tabular}

Sumber: Survei PSAA

Dari tabel tersebut terlihat bahwa sebagian besar anak asuh adalah mereka yang dikategorikan sebagai anak terlantar dan masih memiliki orang tua yang lengkap yaitu $48 \%$ sedang yang kedua adalah anak yatim $(45,3 \%)$.

Tabel 2. Usia Anak Asuh

\begin{tabular}{|c|l|c|c|c|}
\hline No & \multicolumn{1}{|c|}{ Usia } & Laki-Laki & Perempuan & Total \\
\hline 1 & Di bawah 5 th & - & - & - \\
\hline 2 & $6-12$ & 14 & 6 & 20 \\
\hline 3 & $13<18$ & 69 & 57 & 126 \\
\hline 4 & Di atas 18 th & 2 & 2 & 4 \\
\hline \multicolumn{2}{|c|}{ Jumlah } & $\mathbf{8 5}$ & $\mathbf{6 5}$ & $\mathbf{1 5 0}$ \\
\hline
\end{tabular}

Sumber: Survei PSAA

Anak asuh di PA Darul Aitam juga dapat dilihat dari tingkat usia mereka. PA Darul Aitam lebih memilih mengasuh anak-anak yang telah memasuki usia sekolah dasar (di atas 5 tahun). 
Tabel 3. Daerah Asal Anak

\begin{tabular}{|c|l|c|c|c|c|}
\hline No & \multicolumn{1}{|c|}{ Daerah Asal } & Laki-laki & Perempuan & Total & Ket. \\
\hline 1 & $\begin{array}{l}\text { Dari desa/kelurahan } \\
\text { Setempat }\end{array}$ & 5 & 9 & 14 & \\
\hline 2 & $\begin{array}{l}\text { Dari kecamatan } \\
\text { Setempat }\end{array}$ & - & 6 & 6 & \\
\hline 3 & $\begin{array}{l}\text { Dari kabupaten/kota } \\
\text { Setempat }\end{array}$ & 67 & 47 & 108 & \\
\hline 4 & Dari lain kabupaten/Kota & 16 & 1 & 17 & $\begin{array}{l}\text { DKI:1, Kalbar: } 2, \\
\text { Kaltim: } 1, \text { NTT: } 1\end{array}$ \\
\hline 5 & Dari luar propinsi & 3 & 2 & 5 & \\
\hline \multicolumn{2}{|c|}{ Total } & 85 & 65 & 150 & \\
\hline
\end{tabular}

Sumber: Survei PSAA

Tabel 3 menunjukkan bahwa meski rentang usia anak didominasi oleh anak-anak yang berusia di atas 6 tahun, namun sebagian besar mereka (84\%) berada dalam rentang usia antara 13 sampai 18 tahun. Usia anak asuh laki-laki termuda adalah 6 tahun dan yang tertua adalah 20 tahun. Sedangkan bagi perempuan yang termuda berusia 9 tahun dan tertua berusia 18 tahun.

\section{Asal Daerah Anak}

Anak PA Darul Aitam umumnya berasal dari lingkungan Lombok Timur sendiri (72\%), namun demikian ada juga mereka yang berasal dari luar provinsi seperti DKI Jakarta, Kalimantan dan Nusa Tenggara Timur meski jumlahnya sangat kecil yaitu 3,34\%.

Untuk kasus anak yang berasal dari luar provinsi tersebut, mereka datang secara khu-sus karena di daerah mereka belum ada panti asuhan cabang Nahdlatul Wathan, jadi ter-paksa harus dikirim ke Panti Darul Aitam yang berada di Lombok Timur ini, yang merupakan pusat dari organisasi besar NW tersebut.

\section{Lamanya Anak Tinggal di PA Darul Aitam}

Anak asuh PA Darul Aitam rata-rata telah tinggal di PA selama 2 sampai di bawah 3 tahun (34\%); sisanya adalah mereka yang tinggal antara 1 sampai di bawah 2 tahun $(20,67 \%)$ dan 4 tahun sampai di bawah 5 tahun (14, 67\%).

Dari tabel 4 terlihat bahwa lamanya anak tinggal di panti hampir merata dari segi jumlah. Hal ini karena rata-rata mereka di panti minimal 3 tahun yaitu untuk menyelesaikan satujenjang studi, tingkat SLTPatau SLTA. Namun demikian tidak jarang yang menyelesaikan kedua jenjang studi tersebut bahkan sampai kuliah.

Tabel 4. Lamanya Anak Tinggal di Panti

\begin{tabular}{|c|c|c|c|c|}
\hline No & Keseluruhan Anak Asuh & Laki-laki & Perempuan & Lama Tinggal \\
\hline 1 & 51 & 27 & 24 & $2-<3$ Tahun \\
\hline 2 & 31 & 22 & 9 & $1-<2$ Tahun \\
\hline
\end{tabular}




\begin{tabular}{|c|c|c|c|c|}
\hline 3 & 22 & 13 & 9 & $4-<5$ Tahun \\
\hline 4 & 21 & 11 & 10 & $3-<4$ Tahun \\
\hline 5 & 16 & 7 & 9 & $5-10$ Tahun \\
\hline 6 & 9 & 5 & 4 & $<1$ Tahun \\
\hline & 150 & 85 & 65 & Total \\
\hline
\end{tabular}

Sumber: Survei PSAA

Perbedaan lama tinggal terjadi disebabkan tahun masuk anak ke panti berbeda-beda. Ada yang memulai masuk panti sejak kelas 1 SMP, 1 SMA, atau bahkan ada yang dari SD, dan ada juga yang pindahan kelas dari sekolah lain.

\section{Permasalahan Anak di Panti}

Kondisi kehidupan dan perkembangan anak-anak asuh di PA Darul Aitam tidak terlepas dari masalah. Selama tahun 2005 ada seorang anak yang kabur karena tidak dapat "beradaptasi" dengan sistem pelayanan yang ada. Selain itu, tidak ada anak asuh yang harus dirujuk ke lembaga pelayanan lainnya, baik karena alasan kesesuaian daya tampung maupun kemampuan pelayanan PA.

\section{Pendidikan Anak}

Seperti gambaran PA yang sudah disebutkan sebelumnya, maka seluruh anak PA Darul Aitam bersekolah di luar lingkungan panti, tapi berada di lingkungan Yayasan Nahdlatul Wathan Pancor. Hal ini mengingat di lingkungan ini juga berdiri beberapa gedung sekolah dan lembaga pendidikan milik organisasi NW.

Dari tabel 5 terlihat bahwa mayoritas anak panti berada pada jenjang pendidikan SLTP dan SLTA. Hal ini karena memang fokus panti ini melayani anak dengan usia sekolah tersebut. Adapun terdapatnya anak dengan usia sekolah TK (1 orang) dan SD (1 orang) adalah pengecualian, biasanya kekhususan kondisi anak yang "memaksa" panti menerimanya. Adapun yang sedang mengenyam pendidikan tinggi ( 1 orang) adalah alumni yang masih mendapat izin tinggal di panti dan pada tahun pertama kuliah masih dianggap sebagai anak asuh meskipun mempunyai peran yang sedikit berbeda, yaitu membantu pengasuh dalam menjalankan keseharian panti.

Tabel 5. Pendidikan Anak

\begin{tabular}{|c|l|c|c|c|}
\hline No & \multicolumn{1}{|c|}{ Pendidikan } & Laki-laki & Perempuan & Total \\
\hline 1 & Prasekolah/TK & 1 & - & 1 \\
\hline 2 & SD/MI & 3 & 2 & 5 \\
\hline 3 & SLTP/MTS & 49 & 32 & 81 \\
\hline 4 & SLTA/MA & 32 & 30 & 62 \\
\hline 5 & Pendidikan Tinggi & - & 1 & 1 \\
\hline \multicolumn{2}{|c|}{ Total } & 85 & - & 150 \\
\hline
\end{tabular}

Sumber: Survei PSAA

Pelayanan pendidikan ternyata tidak diikuti oleh pelayanan lainnya kecuali pelatihan keterampilan. Dalam keterampilan, hampir semua anak (kecuali anak laki-laki usia 6 tahun) 
dilatih untuk membuat paving block dan batako. Pelatihan ini selain karena kebutuhan panti juga prosesnya sangat praktis, yaitu pelibatan dalam pembuatan benda-benda yang amat dibutuhkan dalam pembangunan panti.

\section{Hubungan Anak dengan Keluarga}

Orang tua atau anggota keluarga adalah pihak utama yang membawa anak-anak mereka ke PA Darul Aitam Pancor dari pada pihak lain. Komposisi orang tua merupakan pihak utama yang mengantar anak-anak mereka memasuki dunia panti $(90,67 \%)$. Sisanya adalah sanak keluarga, dalam pengertian keluarga besar anak seperti paman, bibi, kakek dsb. Selengkapnya dapat dilihat pada tabel 6.

Tabel 6. Pihak yang Mengantar Anak ke Panti

\begin{tabular}{|l|l|c|c|c|}
\hline No & Pihak Pengantar & Laki-laki & Perempuan & Total \\
\hline 1 & Orangtua & 80 & 56 & 136 \\
\hline 2 & Sanak keluarga & 5 & 9 & 14 \\
\hline \multicolumn{2}{|c|}{ Total } & 85 & 65 & 150 \\
\hline
\end{tabular}

Sumber: Survei PSAA

Hubungan anak dengan orang tua dan keluarga diwujudkan dalam jumlah kunjungan orang tua dan keluarga mereka ke panti. Dalam kunjungan anak dan keluarga ini diperoleh data sebagaimana ditampilkan dalam tabel 7.

Dari data tersebut terlihat bahwa ada sejumlah besar anak yang tidak pernah dikunjungi keluarga mereka (70 orang). Hal ini karena sangat terbatasnya kondisi keuangan mereka, yaitu dengan jarak antara rumah dan tempat panti yang berada sangat jauh memerlukan biaya transportasi yang mahal, sehinga mereka hanya mengandalkan kepulangan anak asuh setahun sekali untuk bertemu. Adapun yang umum terjadi ( 59 orang) adalah mereka mendapat kunjungan 1 tahun sekali, di mana keluarga mereka menyempatkan dan menyiapkan diri untuk melakukan perjalanan ke panti untuk menemui anak asuh.

Tabel 7. Kunjungan Keluarga kepada Anak

\begin{tabular}{|c|l|c|c|c|}
\hline No & Jumlah Kunjungan & Laki-laki & Perempuan & Total \\
\hline 1 & Tidak pernah & 53 & 17 & 70 \\
\hline 2 & 1 kali pertahun & 26 & 33 & 59 \\
\hline 3 & $>5$ kali pertahun & 5 & 5 & 11 \\
\hline 4 & $>1$ kali perbulan & 1 & 10 & 10 \\
\hline 5 & $>1$ kali perminggu & - & - & - \\
\hline \multicolumn{2}{|c|}{ Total } & 85 & 65 & 150 \\
\hline
\end{tabular}

Sumber: Survei PSAA

Selain itu, hubungan antara anak dan orang tua/keluarga juga diwujudkan dalam kunjungan anak ke orang tua/keluarga mereka. Dalam hal ini meskipun kebanyakan anakanak Darul Aitam (65,4 \%) berasal dari Lombok Timur, namun ternyata ada anak-anak yang tidak pernah pulang sama sekali selama 2005, yaitu sebanyak 34,67 \% anak. 
Dari paparan tentang profil di atas dapat diketahui bahwa secara umum panti ini termasuk panti yang cukup terorganisasi dengan baik. Namun terdapat banyak kekurangan, baik secara fisik maupun praktik profesional dalam penyampaian pelayanan anak. Sehingga, jika diukur dari standar kualitas pelayanan anak yang berbasis hak-hak anak maka akan banyak sekali ditemui kegiatan dan fasilitas yang tidak memenuhi standar.

Secara umum, pendidikan formal dan informal relatif terpenuhi dengan baik. Namun kebutuhan dasar anak secara fisik dan emosional masih sangat terbatas. Sebagai panti yang berbasis pesantren (pendidikan Islam), kekurangan dan keterbasan secara fisik dianggap merupakan salah satu perjuangan dalam menuntut ilmu. Kerja keras yang dilakukan selama di panti mereka anggap sebagai jihad yang memiliki nilai ibadah yang sangat tinggi.

Dengan keterbatasan tersebut, pihak panti menghendaki anak-anak lebih survive ketika keluar dari panti. Tradisi ini memang telah mendulang banyak bukti kesuksesan yaitu dengan lahirnya anak-anak yang kuat dan tangguh dalam menjalani hidup - namun praktik ini harus diimbangi dengan pengetahuan tentang hak-hak anak, sehingga pengurus panti mengetahui pada batas mana mereka boleh menggembleng kemandirian anak dengan cara mereka.

Celah kekerasan terhadap anak terdapat pada tradisi kepatuhan anak terhadap pengasuh yang relatif tinggi. Hal ini karena pengasuh ada yang merangkap sebagai guru sedangkan status guru di mata santri adalah hampir "segalanya". Guru dianggap yang paling benar dan harus ditiru, sehingga tidak ada yang berani menolak apapun yang dikatakannya.

Secara identitas, Panti Sosial Asuhan Anak Darul Aitam ini dapat dikatakan jelas, yaitu terpenuhinya beberapa persyaratan untuk dapat dikatakan sebuah lembaga resmi yang bergerak di bidang pelayanan anak dalam bentuk panti-seperti nama panti dan kepala panti, alamat, tahun berdiri dan mulai beroperasi, status kepemilikan, organisasi yang memayungi, jenis pelayanan dan program, serta kelengkapan administratif untuk dapat dikatakan dan beroperasi sebagai panti-dengan segala kekhasan yang ditawarkannya.

Dari segi pendanaan, seperti halnya panti sosial pada umumnya, sumber dana utama adalah dari masyarakat umum yang disebut donatur, baik perorangan maupun kelompok atau organisasi, dan pada masa tertentu juga diperoleh dari pemerintah. Hal ini jelas berimplikasi pada jumlah pemasukan yang selalu dalam kondisi tidak tetap. Padahal, pengeluaran perhari bersifat tetap bahkan sangat jelas dan dapat dikalkulasi. Ketimpangan dalam neraca keuangan ini, yang mana pemasukan sangat jauh dari yang diharapkan untuk dapat memenuhi semua kebutuhan keuangan panti, berimplikasi pada buruknya pelayanan panti dari berbagai aspek seperti praktik profesional, personal care, pengaturan staf, dan lain sebagainya.

Dari segi sumber daya manusia, dengan jumlah anak asuh yang jauh lebih banyak (150 anak) dari jumlah pengasuh (5-7 orang), jelas ini tidak memenuhi standar nasional pelayanan panti. Belum lagi dari segi pendidikan yang dibutuhkan untuk dapat disebut sebagai pengasuh yang profesional (terdidik dan terlatih di bidang pengasuhan anak), maka tidak satu pun SDM yang memenuhi kriteria tersebut. Begitu juga dari segi sarana dan prasarana yang belum proporsional dan fungsional, baik dari segi jumlah atau kuantitas maupun kualitas.

Berkaitan dengan kualitas pelayanan anak di panti, berikut ini kesimpulan dari 5 aspek yang diteliti. 


\section{Praktik Profesional}

Maksud dan tujuan panti tidak dirumuskan secara spesifik, tetapi menginduk pada maksud dan tujuan pendirian Yayasan Nahdlatul Wathan sebagai organisasi payungnya. Nilai yang dianut adalah nilai ajaran Islam dan semua staf memahami nilai tesebut karena telah terdidik dalam kurun waktu yang lama di lembaga-lembaga pendidikan di bawah yayasan. Sejauh yang dipersepsikan oleh para pengurus dan anak asuh, maksud dan tujuan panti dianggap telah dirumuskan berdasarkan kepentingan terbaik anak-anak asuh, khususnya di bidang pendidikan. Akan tetapi, jika dibaca dalam konteks hak-hak perlindungan anak, maka maksud dan tujuan itu memang masih bias kepentingan pengelola, belum mencerminkan kepentingan anak yang sesungguhnya.

Mengenai perlindungan anak, secara formal tidak ada kebijakan tentang perlindungan anak yang disusun oleh panti. Pihak panti sendiri belum mengetahui secara jelas apa itu perlindungan anak. Dengan mendirikan panti dan memberi pelayanan terhadap anak dari keluarga miskin itu sudah dianggap memberi perlindungan anak. Di dalam panti sendiri para pengurus dan pengasuh mencoba untuk tidak menyakiti, memukul, menyengsarakan, atau menelantarkan baik fisik maupun mental, rohani dan jasmani anak-anak asuhnya. Karena itu, menurut persepsi pihak panti, di PSAA Darul Aitam belum terjadi kekerasan. Wajar kalau kemudian pihak panti tidak pernah berfikir untuk menyusun kebijakan perlindungan anak di panti.

Pihak panti hanya menyusun aturan sanksi bagi anak-anak yang melanggar aturan, yaitu dengan beberapa kali teguran sesuai dengan pendekatan ajaran Islam, yaitu diberi nasihat dulu (mau'idzah hasanah) baru jika tidak bisa maka diberi tindakan. Tindakan itu seperti hukuman pukulan ringan bagi anak yang tidak sholat didasarkan pada hadis Nabi, bahwa jika anak telah berumur 10 tahun tidak melaksanakan sholat maka boleh dipukul untuk mendidiknya. Adapun jenis hukuman yang lainnya, seperti tidak diberi makan dll, sebenarnya adalah variasi dari hukuman pukulan, meskipun tidak ada hadis Nabi yang merinci soal itu namun argumentasi yang dibangun adalah demi mendidik sang anak asuh yang menjadi spirit hadis Nabi tersebut. Anak-anak asuh paham betul tentang argumentasi tersebut sehingga mereka sudah mengerti dan paham akibat dari pelanggaran yang mereka perbuat.

Pemahaman pengurus panti tentang perlindungan anak masih sangat sederhana. Menurut penuturan salah seorang staf, pelayanan yang mereka berikan di panti terhadap anak merupakan bentuk dari perlindungan anak. Masih terbatasnya pemahaman pengurus tentang perlindungan anak, karena sumber bacaan mereka terbatas, dan di antara mereka belum pernah ada yang mengikuti pelatihan tentang perlindungan anak.

Meskipun pengurus maupun pengasuh menyatakan bahwa tidak ada kekerasan di panti, namun kekerasan sebenarnya ada dan cenderung muncul saat anak melakukan kesalahan atau indisipliner. Bagi anak-anak yang melakukan indisipliner, pihak panti mencoba mengembangkan metode sanksi dengan pendekatan Islam. Bagi anak-anak yang melanggar, mereka akan dipanggil dan diberi nasehat. Menurut penuturan seorang staf, pendekatan ini dikembangkan karena mereka adalah guru, bukan ABRI.

Beberapa pengurus panti menyatakan tidak pernah terjadi kekerasan. Hal tersebut juga disampaikan oleh anak-anak ketika ditanya tentang kekerasan. Namun apabila ditanya tentang siapa yang pernah dipukul karena tidak ikut kegiatan, banyak anak yang menyatakan 
pernah. Bentuknya adalah pukulan, kata-kata kasar, dan digundul. Pada umumnya, hukuman itu diberikan kepada anak-anak yang tidak naik musholla. Naik mushola adalah salah satu aktivitas anak pada pagi hari jam 04.00 sampai dengan jam 05.30 yang bertempat di musholla. Mereka tidak naik mushola pada umumnya karena kesiangan bangun.

Anak-anak tidak menyadari bahwa apa yang diterimanya adalah satu bentuk kekerasan. Menurut DuBois (1992, hal. 393) bahwa pemukulan termasuk dalam physical abuse. Sedangkan membentak, mempersalahkan termasuk dalam emosional abuse. Mereka menganggap bahwa yang telah mereka terima adalah suatu bentuk hukuman karena mereka telah melalaikan tugas dan tanggung jawab. Mereka menerimanya, tanpa perasaan sakit hati, namun malah tumbul rasa bersalah dan penyesalan untuk tidak mengulanginya.

PSAA Darul Aitam, adalah panti yang berbasis pesantren, sehingga tidak heran apabila semua pendekatan yang dikembangkannya adalah agama. Kemungkaran yang dimaksud oleh pengasuh di dalamnya adalah pelanggaran yang dilakukan oleh anak. Oleh karena itu setiap pelanggaran adalah kemungkaran, dan bagi mereka yang melakukannya harus diberi hukuman. Hukumannya bertahap mulai dari pemberian nasehat. Pemberian nasehat ini mereka sebut dengan pendekatan fa bilisanih (dengan lisan). Apabila dengan lisan tidak berhasil, maka didiamkan. Mendiamkan pelanggaran mereka sebut dengan pendekatan $f a$ biqolbih (denga hati). Pendekatan ini dianggap pengurus/pengasuh sebagai paling lemahnya iman. Pengasuh menganalogikan dengan pendekatan ABRI. Apabila nasehat tidak mempan, maka harus dilakukan tindakan tegas berupa hukuman dengan maksud mendidik, meski mereka tidak mengakui bentuk-bentuk hukuman yang mereka berlakukan sebagai kekerasan.

Mengenai penerimaan anak asuh, panti memiliki proses atau tahapan sendiri berikut kriteria-kriteria penerimaannya. Biasanya, orang yang terlibat dalam penyerahan anak ke panti adalah keluarga atau sanak famili dan pengurus cabang Yayasan Nahdlatul Wathan yang mengajukan anak tersebut menjadi anak asuh Darul Aitam. Dalam kondisi panti yang terbatas dan tidak mungkin menerima semua pengajuan dari cabang, maka isu pemerataan wilayah dan keterjangkauan dakwah menjadi fokus utama dibanding kondisi spesifik anak, sehingga anak yang datang dari wilayah yang sepi kader Nahdlatul Wathan menjadi priorias. Panti tidak mengenal rencana pelayanan individual (care plan) untuk masing-masing anak asuh. Begitu pula dengan review. Semua pelayanan berjalan layaknya pendidikan pesantren. Bedanya hanya pada kenyataan bahwa para santri adalah anak asuh yang dibebaskan dari segala biaya. Dalam hal pelayanan, kelanjutan dan pasca pelayanan juga demikian. Anak asuh yang sudah menyelesaikan pendidikan formal di lembaga di bawah yayasan berarti sudah saatnya mereka kembali ke keluarganya.

Tidak ada perencanaan khusus mengenai kelanjutan hidup mereka selepas dari panti. Semua dipersiapkan sendiri oleh anak selama menjalani pendidikan. Hanya nasehat dan saran yang bisa diberikan pengasuh, bukan program terencana. Mengenai anak yang tidak betah atau "kabur" dari panti, pihak panti pun tidak mempunyai suatu prosedur khusus. Semua itu ditangani secara tradisional dan kekeluargaan.

\section{Personal Care}

Meskipun standar 3 kali makan dalam sehari terpenuhi, namun dengan dana makan anak Rp 1000 sekali makan, maka menu yang dikonsumsi anak setiap harinya jauh dari 
4 sehat 5 sempurna. Tidak ada pertimbangan penyesuaian kebutuhan makan anak sesuai perkembangan usia atau kondisi spesifik anak. Peralatan dan fasilitas makan anak pun masih sangat minim sehingga tidak memenuhi aspek kenyamanan dan keamanan dari segi kesehatan. Meski demikian, hal ini tidak dirasakan sebagai sesuatu yang menghalangi mereka untuk bisa tetap riang gembira saat makan.

Dari segi kesehatan, panti ini relatif memperhatikan sejauh kemampuan yang bisa mereka berikan. Selain mendidik anak-anak supaya hidup bersih dan sehat-dalam kondisi keterbatasan fasilitas - panti juga menyediakan layanan kesehatan dalam bentuk Puskespan (Pusat Kesehatan Panti) dengan seorang tenaga medis dan persediaan obat yang mencukupi. Hanya saja, panti ini masih perlu mendapat informasi dan penyuluhan serta pendidikan kesehatan dari pihak luar, karena belum mampunyai sepenuhnya memadai.

Kegiatan bermain, rekreasi, pemanfaatan waktu luang dan kesenian masih minim baik dari segi kesempatan waktu maupun dari segi fasilitas. Demikian juga halnya dengan privasi anak yang belum bisa terpenuhi secara maksimal baik dari fasilitas yang sifatnya fisik maupun dalam perlakuan khusus yang sifatnya psikologis. Dalam hal ini, tidak banyak pilihan yang dapat dibuat sendiri oleh anak asuh.

Secara umum, semua staf panti memang mengakui dan menghargai bahwa setiap anak mempunyai pribadi yang berbeda. Namun, pelayanan berbasis perbedaan dan keunikan pribadi itu belum dilakukan. Bahkan, sadar atau tidak, staf telah membuat malu anak-anak asuh terutama perempuan dengan kegiatan mengangkut kayu bakar.

Relasi sosial dan kelekatan antara anak asuh dengan staf/pengasuh maupun sesama anak terjalin dengan baik. Meski rasa hormat terhadap pengasuh yang juga merangkap guru mereka kadang menciptakan jarak antara mereka dan anak, namun keterbukaan pengasuh yang sehari-hari berada di asrama mampu meretas dan mencairkan kebekuan suasana.

Tidak ada program atau pembiasaan khusus yang dicanangkan panti untuk menumbuhkan dan memelihara kesadaran identitas anak. Yang ada malah ditonjolkannya keseragaman antar anak untuk mencapai keharmonisan antara mereka. Hal tersebut lambat laun mungkin saja akan melunturkan kesadaran identitas mereka, meski belum terbukti.

Pengasuhan, pengendalian dan sanksi di Panti Asuhan Darul Aitam mewujud dalam peraturan. Kehidupan yang diatur oleh jadwal yang ketat dan peraturan yang tegak membuat anak asuh di satu sisi menjadi sangat disiplin dan pada sisi lain cukup mengekang kebebasan. Akan tetapi, anak-anak tidak bisa menyuarakan keinginan mereka karena tidak ada media yang dapat membuat anak nyaman untuk menyampaikannya.

Pendidikan adalah pelayanan yang paling menjadi prioritas dan menjadi perhatian utama panti. Parameter kesuksesan dalam pengasuhan tak jarang diukur dari keberhasilan atau prestasi anak dalam pendidikan formal. Pihak sekolah pun cukup mampu dan terbiasa mengomunikasikan permasalahan anak panti di sekolah, sehingga tidak ada hambatan berarti bagi anak asuh untuk mengenyam pendidikan. Malah tak jarang faktor ingin mendapatkan pendidikan yang baik menjadi alasan para keluarga yang tidak mampu menitipkan anaknya di panti ini.

\section{Pengaturan Staf}

Mengenai pengaturan staf, tidak ada perekrutan dan seleksi khusus mengingat tidak ada sesuatu yang ditawarkan pihak panti untuk seseorang yang akan menjadi staf atau pen- 
gasuh kecuali nilai pengabdian dalam mengurus anak-anak yatim. Ini disebabkan tidak ada dana khusus dalam bentuk gaji atau honor untuk mereka. Karenannya, perekrutan lebih karena faktor kekeluargaan dan kekerabatan. Namun demikian, kondisi ini tidak menyurutkan semangat mereka untuk bekerja secara baik sesuai dengan tugasnya. Justru mereka bekerja dengan sangat baik dengan segala keterbatasannya karena sebagian besar staf/pengurus/ pengasuh/petugas adalah alumni anak asuh yang kemudian mempunyai jiwa pengorbanan yang tinggi.

Tidak ada supervisi dan dukungan khusus dari pihak atasan, yayasan atau ketua panti kecuali dalam rapat bulanan yang akan dibahas semua permasalahan yang ada. Dari segi pendayagunaan staf dan petugas memang masih minim di mana rasio anak dan petugas masih jauh dari standar. Petugas yang ada pun tidak memperoleh pelatihan dan pengembangan profesional khusus dalam hal pengasuhan anak.

\section{Sumber-Sumber}

Dari segi lokasi, panti ini mudah diakses oleh masyarakat. Interaksi dengan masyarakat berjalan begitu baik dan tidak pernah terjadi konflik. Hanya saja partisipasi masyarakat dalam pencapaian tujuan panti belum terasakan secara maksimal. Tidak ada program pelayanan anak di luar panti. Semua pelayanan dikonsentrasikan pada anak-anak di dalam panti.

Dari sisi akomodasi, hampir seluruh ruangan di panti ini mengandung kekurangan. Hanya mushola yang dapat dikatakan nyaman dan aman, baik dari segi fungsionalnya maupun estetikanya. Di antara fasilitas yang serba kurang nyaman itu adalah fasilitas MCK yang terlihat paling memprihatinkan.

\section{Administrasi}

Dalam hal administrasi, tidak ada file lain tentang anak kecuali data biografi singkat yang tercantum dalam buku induk. Begitu pula tidak ada file khusus untuk setiap anak yang memuat riwayat anak dan catatan perkembangan anak. Terlebih lagi tentang staf. Tidak ada satu catatan pun yang memuat data tentang pengurus/staf/pengasuh/petugas. Catatan yang dapat dinilai cukup baik hanyalah catatan mengenai keuangan. Semua ini mencerminkan lemahnya tradisi administrasi yang baik di panti.

Selanjutnya, karena dikelola bersama secara kekeluargaan, maka hampir tidak ada aturan kerahasiaan di antara pengurus. Yang diterapkan hanyalah komunikasi yang tidak tersumbat sehingga siapa pun yang akan melakukan sesuatu berkaitan dengan administrasi panti diketahui dengan baik oleh yang lain.

Sedangkan keterlibatan Kepala Panti di Panti Asuhan Darul Aitam ini lebih banyak di level kebijakan dan hubungan luar panti. Adapun keterlibatan dengan Dinas Sosial sifatnya adalah pembinaan, dan Yayasan Nahdlatul Wathan terhadap panti hubungannya bersifat konsultatif.

\section{Penutup}

Hasil penelitian Kualitas Pengasuhan Anak di PSAA Darul Aitam menunjukkan bahwa ada beberapa hal yang perlu dibenahi dalam penyelenggaraan pengasuhan. Tentunya PSAA Nahdlatul Wathan tidak bisa berdiri sendiri dalam upaya pembenahan tersebut. Semua 
pihak harus mendukung untuk melakukan perbaikan kualitas pelayanan baik pihak yayasan maupun pemerintah daerah terkait.

Bagi pihak pengurus internal panti, ada beberapa hal yang perlu direkomendasikan terutama dalam hal pendanaan panti. Di sini perlu dipikirkan strategi fundrising panti secara lebih inovatif, kreatif, dan variatif. Dengan demikian, pos-pos anggaran yang mesti tercukupi dengan baik seperti honor SDM, operasional panti, pembangunan dan perbaikan fasilitas panti yang telah rusak parah terutama segala kebutuhan pokok anak asuh dapat dipenuhi secara opimal.

Selain itu, karena panti ini belum mempunyai visi dan misi yang terpisah dari visi dan misi yayasan, maka untuk ke depan pihak panti sebaiknya merumuskannya demi arah pengembangan panti. Perumusan ini sebaiknya juga melibatkan seluruh elemen panti termasuk anak asuh sehingga perspektif mereka dapat terakomodir dan terarah panti pada kepentingan anak asuh.

Dalam hal peraturan dan sanksi terhadap anak asuh, hendaknya pihak panti memadukan antara sumber-sumber ajaran Islam — sebagai justifikasi hukuman atas tindakan indisipliner misalnya - dengan wawasan tentang perlindungan anak. Dengan demikian tidak akan terjadi hukuman yang mengganggu kondisi fisik atau psikis anak, mengganggu perkembangan mental anak atau menodai martabat anak.

Dalam hal penerimaan anak asuh, selain diperhatikan kondisi sosial dan ekonomi anak, sebaiknya diperhatikan juga kondisi psikologis (psikis) anak. Hal ini untuk mendeteksi apakah anak punya masa lalu yang kelam yang kemungkinan dapat menghambat perkembangannya seperti mengalami kekerasan, mengalami trauma mendalam karena kehilangan, dan lain-lain.

Dari sisi kelengkapan arsip, maka persyaratan masuk panti sangat penting disertakan akta kelahiran anak mengingat akta kelahiran termasuk di antara hak anak. Sedangkan mengenai kuota anak asuh, sebaiknya panti lebih cermat memperhitungkan kesanggupan pembiayaan panti untuk menampung anak asuh, sehingga tidak terjadi "ketelantaran" pelayanan. Selain itu, dalam memilih prioritas anak yang diterima, sebaiknya panti lebih memperhatikan kondisi riil anak ketimbang pemikiran tentang prospek penyebaran kader.

Sementara itu, dari segi pelayanan, ada baiknya panti mencoba untuk memulai dengan sistem pelayanan yang lebih individual dengan cara membuat rencana pelayanan individual, sehingga perkembangan anak dan arah pelayanan anak tidak selalu bersifat general dan massal. Baik juga bagi panti memulai untuk melakukan review penempatan anak untuk melihat kembali tepat-tidaknya anak berada di panti.

Sebagai rasa tanggung jawab panti terhadap anak asuh serta dalam rangka mempersiapkannya menjadi alumni, sebaiknya pula panti membekali anak dengan pendidikan life skill sehingga alumni mempunyai lapangan kerja yang jelas bahkan mampu menciptakan lapangan kerja sendiri.

Mengenai personal care, panti sebaiknya memperhatikan kecukupan gizi makanan anak seperti memberikan buah dan susu serta makanan tambahan seperti snack dan kacang hijau secara temporer. Dari segi pelayanan kesehatan sebenarnya panti ini sudah maju dengan adanya Puskespan, hanya saja mungkin perlu ada pemeriksaan rutin pada tiap anak sebagai 
upaya pemeliharaan kesehatan. Panti juga harus menyediakan kegiatan bermain, rekreasi, pemanfaatan waktu luang dan kesenian yang sesungguhnya dan mencukupi dari segi waktu, bukan sekedar kegiatan sambilan.

Untuk tenaga SDM atau staf, sebaiknya panti mulai memikirkan agar menjadikan panti ini lebih terorganisir dengan lebih baik, yaitu dengan mengadakan perekrutan dan seleksi untuk semua posisi seperti pendidik, pengasuh, pekerja sosial, psikolog, petugas medis, dan juru masak. Supervisi dan dukungan juga harus seratus persen diberikan pihak panti kepada para staf tersebut.

Panti juga perlu membenahi sistem administrasi. Semua kegiatan sebaiknya ada catatannya (jurnal harian) dan setiap anak mempunyai file riwayat hidup dan catatan perkembangannya dengan baik. Demikian pula dengan file karyawan atau staf. Jika semua catatan atau rekaman telah terealisasi, maka perlu juga diatur tentang kerahasiaannya mengenai siapa yang bertanggungjawab memegang dan siapa saja yang boleh mengaksesnya.

Soal kekerasan, celah kekerasan memang muncul dan dipelihara lebih banyak dalam praktik pendisiplinan anak. Namun sebenarnya tidak-terpenuhinya kelima aspek standar pengasuhan anak tersebut juga berkontribusi pada terciptanya celah kekerasan terhadap anak asuh di PSAA Darul Aitam. Ketika praktik profesional, personal care (pemeliharaan diri anak), pengaturan staf, sumber-sumber, dan administrasi di panti dilakukan dengan standar praktik terbaik dan berfokus pada kepentingan anak, maka celah kekerasan di PSAA dapat diminimalisir bahkan ditiadakan sama sekali.

Adapun bagi pihak Yayasan Nahdlatul Wathan, penelitian ini merekomendasikan bahwa Yayasan Nahdlatul Wathan sebaiknya tidak menutup mata akan kondisi yang sebenarnya terjadi di panti. Segala kekurangan yang secara kasat mata terlihat dan semua yang dilaporkan panti harus dibantu untuk menemukan solusinya, terutama dalam hal keuangan (pendanaan). Selain itu, supervisi dan monitoring harus secara terencana dilakukan di semua aspek panti terutama terhadap pengembangan SDM panti.

Rekomendasi untuk pihak pemerintah, sebagai pihak yang wajib melindungi dan menjamin kesejahteraan anak, adalah perlunya melakukan sosialisasi tentang hak-hak perlindungan anak kepada masyarakat luas. Pemerintah juga perlu menyediakan anggaran yang memadai untuk membina dan memerhatikan panti-panti berisi anak-anak yang harus dipelihara oleh negara. Pemerintah harus secara serius menyelenggarakan program-program pembinaan panti agar pihak panti benar-benar menjalankan tugas sesuai dengan fungsinya.

Selain itu, sangat diperlukan kebijakan dan peraturan baku serta pengawasan dan bimbingan yang terstruktur dari pemerintah terhadap kualitas pelayanan anak berbasis hakhak anak, bukan hanya pengawasan teknis dan audit keuangan saja seperti yang selama ini dilakukan. Dengan demikian, audit juga dilakukan terhadap semua aspek pelayanan dari aspek praktik profesional, personal care, pengaturan staf, sumber-sumber, dan administrasi. Dari sini dapat dilakukan sertifikasi atau bahkan likuidasi terhadap pantipanti yang menyeleweng. 


\section{Bibliografi}

Fuaida, Lisma Dyawati, dkk, Laporan Penelitian Kualitas Pengasuhan Anak di Panti Sosial Asuhan Anak (PSAA) di Indonesia: PSAA Darul Aitam Nahdlatul Wathan Kabupaten Lombok Timur Provinsi Nusa Tenggara Barat. Jakarta: Save the Children UK, Depsos RI, UNICEF, 2007.

http://www.bps.go.id/sector/population/table1.shtml

Martin, Florence, dkk. Seseorang yang Berguna: Kualitas Pengasuhan di Panti Sosial Asuhan Anak di Indonesia. Jakarta: Save the Children UK, Depsos RI, UNICEF, 2007.

Miles, Matthew B dan A. Michael Huberman. Analisis Data Kualitatif: Buku Sumber Tentang Metode-metode Baru. Jakarta: UI-Press, 1992.

Swales, D Applying the Standards-improving quality child care provision in East and Central Africa. UK: Save the Children UK, 2006.

Undang-Undang Republik Indonesia Nomor 23 Tahun 2002 tentang Perlindungan Anak. Jakarta: Kementerian Pemberdayaan Perempuan RI, 2002.

Dubois, Brenda, Social Work An Empowering Profession, Boston: tnp, 1992. 